\title{
Determinants and distribution of out of pocket ex- penditure for health care services in a district of western Maharashtra, India: An Observational Study.
}

Dr. Prakash Kalke ( $\sim$ prakash.kalke@gmail.com )

Symbiosis International University

Dr. Darshana Mundhe

Bharati Vidyapeeth Deemed University

Dr. Dharmendra Kumar Dubey

Symbiosis International University

\section{Research Article}

Keywords: determinants, distribution, health care services, households, out of pocket expenditure

Posted Date: February 23rd, 2021

DOI: https://doi.org/10.21203/rs.3.rs-207143/v1

License: (c) (i) This work is licensed under a Creative Commons Attribution 4.0 International License.

Read Full License 


\section{Abstract}

Background: Reliability on out of pocket expenditure (OOPE) for health care services is commonly seen among the Indian population. There are various determinants which affect the OOP health expenditure.

Aim: The aim of this study was to identify the impact of socioeconomic, demographic, and educational factors on OOPE and distribution of it among various components of health care services and diseases among the households of Pune district of Maharashtra.

Method: An observational study was considered for primary data collection. Total 415 households were surveyed and out of them 353 were considered for analysis. Cross-tabulation and chi-square test was used to find out the significant relationship between the different variables.

Result: It was found that the area of residence, age, gender, and type of disease, marital status, level of education, socioeconomic status of households have significant relationship with OOPE. The medicine purchase had greatest impact on OOPE followed by OPD and IPD services. Non-communicable diseases increase the burden on OOPE.

Conclusion: Households should be made aware of various modes of healthcare financing; simultaneously government should improve penetration of existing social health insurance schemes. The policy makers should consider the factors mentioned and increase spending on public health to strengthen the existing facilities to further reduce the OOPE burden related to healthcare services.

\section{Introduction}

Out of pocket expenditure (OOPE) is "The expenses that the patient or the family made directly to public or private health care providers at the point of receiving health services, without a third-party (insurer, or State)"(WHO). Whereas catastrophic health expenditure is defined as out-of-pocket spending for health care that exceeds a certain proportion of a household's income with the consequence that household suffer the burden of disease. $(1,2)$ Catastrophic expenditure is common in low and middle income countries where healthcare is mainly financed by the people through OOPE and less common in high income countries with established prepayment methods. (3) As per WHO data OOPE in 2016 was around $64.57 \%$ of total health expenditure.(4) Catastrophic OOPE pushed 100 million individuals across globe below poverty line and another 150 million faced financial difficulties due to direct health expenditure payment. $(3,5)$ Reliability on OOPE increases financial burden on impoverished population which creates inequalities in accessing healthcare facilities with an impact that the poor people stop using the services as they cannot afford the direct cost.(5) OOPE is common in India, where, according to a recent survey, only $15 \%$ (50 234/333 104) of the population is covered by health insurance. (6) Public expenditure on health in India has remained stagnant at 1\% of gross domestic product (GDP) till 2012 which merely increased to 1.17 per cent of GDP in 2016. In comparison to that, countries classified as lower income countries spend around 1.57 per cent of GDP on health. $(7,8)$ Studies have also found healthcare expenditure to be closely linked to family income and highly correlated with low-income status. $(9,10)$ 
Many factors, such as the availability of health services, financial resources, perceived and actual needs for healthcare, and patient satisfaction etc., contribute to healthcare utilization, which is reflected in overall OOPE at the individual and/or household level. (10-15) Out of the many financing mechanisms, OOPE is considered to be the most unfair for the poor.(15) Therefore, policy-makers should define the factors that make households vulnerable to use OOPE as means of healthcare financing. Health care services like outpatient department (OPD) based services, inpatient department (IPD) based services, medicine purchase, laboratory and radiological investigations attract increased expenditure. This study determines the impact of socioeconomic, demographic, and educational factors on OOPE and distribution of OOPE for the various components of health care services among the households of Pune district of Maharashtra.

\section{Method}

An observational study was conducted among the households of Pune district of Maharashtra, India. Pune district has mixed strata of rural, urban and urban slum population which is ideal representation of population of Maharashtra. A structured questionnaire was used. Variables considered were (a) demographic factors: area of residence, age, gender, marital status, (b) socioeconomic factors: number of dependent members, number of earning members, gross monthly income, (c) educational factors : school level, graduate, post graduate (d)health care service related factors : monthly percentage income spent on healthcare of the family members, mode of availing health services(OOPE, health insurance (HI), mixed of both and other options which includes, public services, charitable facilities, donations, home remedies etc), gross health expenditure on various healthcare services (OPD, IPD, Medicine purchase, Laboratory/Radiological investigations)and disease wise health expenditure. Data was collected through household survey by students under a subjective assignment for a period of December 2019 to Feb 2020. For this purpose, total 415 households were surveyed, out of which 353 observations were eligible for analysis (incorrect, incomplete filled forms, those who had not incurred any health expenditure in past one year were not included). Questionnaires were anonymous and participation was voluntary. Completely answering the questionnaire given was considered as consent from the households for the participation in the study. Cross-tabulation was used to summarize the determinants and distribution of OOPE. Chi-square test was also used to identify the association between dependent and independent variables.

\section{Results}

\section{Background Characteristics of Study Participants}

The characteristics of the household's participating in the study are depicted in Table 1.To summarize, $52.12 \%$ were male participants and $47.87 \%$ were female participants; $54.95 \%$ were $25-40$ years of age, $24.64 \%$ were $40-60$ years of age. $25.21 \%$ had school level education, $40.23 \%$ were graduate; $66.01 \%$ were married; $41.93 \%$ were private employees. More than $75 \%$ of the households had income level above 20,000 INR per month. Most of the families were nuclear, only $6.80 \%$ had more than 5 dependent 
members. $87.81 \%$ of households were from urban areas, out of which $3.96 \%$ were from urban slum area; $12.18 \%$ belong to rural communities. $45.04 \%$ had one earning member, $43.34 \%$ had two earning members whereas only $11.61 \%$ had 3 and more earning members in their family. 
Table 1

Characteristics of Participants

\begin{tabular}{|c|c|c|}
\hline Characteristics & $\mathbf{N}$ & $\%$ \\
\hline \multicolumn{3}{|l|}{ Area of residence } \\
\hline Rural & 43 & $12.18 \%$ \\
\hline Urban & 296 & $83.85 \%$ \\
\hline Urban Slum & 14 & $3.97 \%$ \\
\hline \multicolumn{3}{|l|}{ Gender } \\
\hline Male & 184 & $52.12 \%$ \\
\hline Female & 169 & $47.88 \%$ \\
\hline Others & 0 & $0 \%$ \\
\hline \multicolumn{3}{|l|}{ Age } \\
\hline $18-25$ & 56 & $15.86 \%$ \\
\hline $26-40$ & 194 & $54.96 \%$ \\
\hline $41-60$ & 87 & $24.65 \%$ \\
\hline Above 60 & 16 & $4.53 \%$ \\
\hline \multicolumn{3}{|l|}{ Occupation } \\
\hline Business & 56 & $15.86 \%$ \\
\hline Govt. Employee & 38 & $10.76 \%$ \\
\hline Private Employee & 148 & $41.93 \%$ \\
\hline Others & 111 & $31.44 \%$ \\
\hline \multicolumn{3}{|l|}{ Education } \\
\hline School Level & 89 & $25.21 \%$ \\
\hline Graduate & 142 & $40.23 \%$ \\
\hline Post Graduate & 122 & $34.56 \%$ \\
\hline \multicolumn{3}{|l|}{ Marital Status } \\
\hline Married & 233 & $66.01 \%$ \\
\hline Unmarried & 120 & $33.99 \%$ \\
\hline \multicolumn{3}{|c|}{ Number of Dependents } \\
\hline $0-2$ & 135 & $38.24 \%$ \\
\hline
\end{tabular}




\begin{tabular}{|lll|}
\hline Characteristics & N & $\%$ \\
\hline 3 & 110 & $31.16 \%$ \\
\hline 4 & 84 & $23.80 \%$ \\
\hline 5 and above & 24 & $6.80 \%$ \\
\hline Number of earning members & & \\
\hline 1 & 159 & $45.04 \%$ \\
\hline 2 & 153 & $43.34 \%$ \\
\hline 3 and above & 41 & $11.61 \%$ \\
\hline Gross Monthly Income & & \\
\hline less tha Rs. 20000 & 69 & $19.55 \%$ \\
\hline Rs. 20000 to Rs. 30000 & 87 & $24.65 \%$ \\
\hline Rs. 30000 to Rs. 50000 & 98 & $27.76 \%$ \\
\hline More than Rs. 50000 & 99 & $28.05 \%$ \\
\hline
\end{tabular}


Table 2

Represents the determinants and distribution modes of expenditure on healthcare and probability value to identify the association between predictors.

\begin{tabular}{|c|c|c|c|c|c|c|}
\hline Characteristics & OOPE* & $H I^{* *}$ & Both & Others & Total & $\begin{array}{l}\mathrm{p} \\
\text { value }\end{array}$ \\
\hline Area of Residence & & & & & & 0.001 \\
\hline Rural & $\begin{array}{l}27 \\
(62.8 \%)\end{array}$ & $\begin{array}{l}8 \\
(18.6 \%)\end{array}$ & $\begin{array}{l}5 \\
(11.6 \%)\end{array}$ & $3(7.0 \%)$ & 43 & \\
\hline Urban & $\begin{array}{l}74 \\
(25 \%)\end{array}$ & $\begin{array}{l}63 \\
(21.3 \%)\end{array}$ & $\begin{array}{l}55 \\
(18.3 \%)\end{array}$ & $\begin{array}{l}104 \\
(35.1 \%)\end{array}$ & 296 & \\
\hline Urban Slum & $\begin{array}{l}10 \\
(71.4 \%)\end{array}$ & $1(7.1 \%)$ & $\begin{array}{l}3 \\
(21.4 \%)\end{array}$ & $0(0.0 \%)$ & 14 & \\
\hline Total & $\begin{array}{l}111 \\
(31.4 \%)\end{array}$ & $\begin{array}{l}72 \\
(20.4 \%)\end{array}$ & $\begin{array}{l}63 \\
(17.8 \%)\end{array}$ & $\begin{array}{l}107 \\
(30.3 \%)\end{array}$ & 353 & \\
\hline Gender & & & & & & 0.001 \\
\hline Male & $\begin{array}{l}62 \\
(33.7 \%)\end{array}$ & $\begin{array}{l}48 \\
(26.1 \%)\end{array}$ & $\begin{array}{l}40 \\
(21.7 \%)\end{array}$ & $\begin{array}{l}34 \\
(18.5 \%)\end{array}$ & 184 & \\
\hline Female & $\begin{array}{l}49 \\
(29 \%)\end{array}$ & $\begin{array}{l}24 \\
(14.2 \%)\end{array}$ & $\begin{array}{l}23 \\
(13.6 \%)\end{array}$ & $\begin{array}{l}73 \\
(43.2 \%)\end{array}$ & 169 & \\
\hline Total & $\begin{array}{l}111 \\
(31.4 \%)\end{array}$ & $\begin{array}{l}72 \\
(20.4 \%)\end{array}$ & $\begin{array}{l}63 \\
(17.8 \%)\end{array}$ & $\begin{array}{l}107 \\
(30.3 \%)\end{array}$ & 353 & \\
\hline Age & & & & & & 0.001 \\
\hline $18-25$ & $\begin{array}{l}29 \\
(51.8 \%)\end{array}$ & $\begin{array}{l}9 \\
(16.1 \%)\end{array}$ & $\begin{array}{l}8 \\
(14.3 \%)\end{array}$ & $\begin{array}{l}10 \\
(17.9 \%)\end{array}$ & 56 & \\
\hline $25-40$ & $\begin{array}{l}53 \\
(27.3 \%)\end{array}$ & $\begin{array}{l}47 \\
(24.2 \%)\end{array}$ & $\begin{array}{l}43 \\
(22.2 \%)\end{array}$ & $\begin{array}{l}51 \\
(26.3 \%)\end{array}$ & 194 & \\
\hline $40-60$ & $\begin{array}{l}22 \\
(25.3 \%)\end{array}$ & $\begin{array}{l}16 \\
(18.4 \%)\end{array}$ & $\begin{array}{l}9 \\
(10.3 \%)\end{array}$ & $40(46 \%)$ & 87 & \\
\hline Above 60 & $\begin{array}{l}7 \\
(43.8 \%)\end{array}$ & $0(0.0 \%)$ & $\begin{array}{l}3 \\
(18.8 \%)\end{array}$ & $\begin{array}{l}6 \\
(37.5 \%)\end{array}$ & 16 & \\
\hline Total & $\begin{array}{l}111 \\
(31.4 \%)\end{array}$ & $\begin{array}{l}72 \\
(20.4 \%)\end{array}$ & $\begin{array}{l}63 \\
(17.8 \% 0\end{array}$ & $\begin{array}{l}107 \\
(30.3 \%)\end{array}$ & 353 & \\
\hline Occupation & & & & & & 0.001 \\
\hline Business & $\begin{array}{l}16 \\
(28.6 \%)\end{array}$ & $\begin{array}{l}8 \\
(14.3 \%)\end{array}$ & $\begin{array}{l}11 \\
(19.6 \%)\end{array}$ & $\begin{array}{l}21 \\
(37.5 \%)\end{array}$ & 56 & \\
\hline Govt. Employee & $\begin{array}{l}16 \\
(42.1 \%)\end{array}$ & $0(0.0 \%)$ & $0(0.0 \%)$ & $\begin{array}{l}22 \\
(57.9 \%)\end{array}$ & 38 & \\
\hline
\end{tabular}

* Out of pocket Expenditure ** Health Insurance 


\begin{tabular}{|c|c|c|c|c|c|c|}
\hline Characteristics & OOPE* & $H^{\star \star *}$ & Both & Others & Total & $\begin{array}{l}p \\
\text { value }\end{array}$ \\
\hline Private Employee & $\begin{array}{l}50 \\
(33.8 \%)\end{array}$ & $\begin{array}{l}45 \\
(30.4 \%)\end{array}$ & $\begin{array}{l}44 \\
(29.7 \%)\end{array}$ & $9(6.1 \%)$ & 148 & \\
\hline Others & $\begin{array}{l}29 \\
(26.1 \%)\end{array}$ & $\begin{array}{l}19 \\
(17.1 \%)\end{array}$ & $8(7.2 \%)$ & $\begin{array}{l}55 \\
(49.5 \%)\end{array}$ & 111 & \\
\hline Total & $\begin{array}{l}111 \\
(31.4 \%)\end{array}$ & $\begin{array}{l}72 \\
(20.4 \%)\end{array}$ & $\begin{array}{l}63 \\
(17.8 \%)\end{array}$ & $\begin{array}{l}107 \\
(30.3 \%)\end{array}$ & 353 & \\
\hline Education & & & & & & 0.001 \\
\hline School level & $\begin{array}{l}13 \\
(14.6 \%)\end{array}$ & $7(7.9 \%)$ & $2(2.2 \%)$ & $\begin{array}{l}67 \\
(75.3 \%)\end{array}$ & 89 & \\
\hline Graduate & $\begin{array}{l}57 \\
(40.1 \%)\end{array}$ & $\begin{array}{l}29 \\
(20.4 \%)\end{array}$ & $\begin{array}{l}32 \\
(22.5 \%)\end{array}$ & $\begin{array}{l}24 \\
(16.9 \%)\end{array}$ & 142 & \\
\hline Post Graduate & $\begin{array}{l}41 \\
(33.6 \%)\end{array}$ & $\begin{array}{l}36 \\
(29.5 \%)\end{array}$ & $\begin{array}{l}29 \\
(23.8 \%)\end{array}$ & $\begin{array}{l}16 \\
(13.1 \%)\end{array}$ & 122 & \\
\hline Total & $\begin{array}{l}111 \\
(31.4 \%)\end{array}$ & $\begin{array}{l}72 \\
(20.4 \%)\end{array}$ & $\begin{array}{l}63 \\
(17.8 \%)\end{array}$ & $\begin{array}{l}107 \\
(30.3 \%)\end{array}$ & 353 & \\
\hline Marital status & & & & & & 0.001 \\
\hline Married & $\begin{array}{l}61 \\
(26.2 \%)\end{array}$ & $\begin{array}{l}54 \\
(23.2 \%)\end{array}$ & $\begin{array}{l}36 \\
(15.5 \%)\end{array}$ & $\begin{array}{l}82 \\
(35.2 \%)\end{array}$ & 233 & \\
\hline Unmarried & $\begin{array}{l}50 \\
41.7 \%)\end{array}$ & $18(15 \%)$ & $\begin{array}{l}27 \\
(22.5 \%)\end{array}$ & $\begin{array}{l}25 \\
(20.8 \%)\end{array}$ & 120 & \\
\hline Total & $\begin{array}{l}111 \\
(31.4 \%)\end{array}$ & $\begin{array}{l}72 \\
(20.4 \%)\end{array}$ & $\begin{array}{l}63 \\
(17.8 \%)\end{array}$ & $\begin{array}{l}107 \\
(30.3 \%)\end{array}$ & 353 & \\
\hline Number of Dependents & & & & & & 0.001 \\
\hline $0-2$ & $\begin{array}{l}48 \\
(35.6 \%)\end{array}$ & $\begin{array}{l}29 \\
(21.5 \%)\end{array}$ & $31(23 \%)$ & $27(20 \%)$ & 135 & \\
\hline 3 & $\begin{array}{l}17 \\
(15.5 \%)\end{array}$ & $\begin{array}{l}30 \\
(27.3 \%)\end{array}$ & $\begin{array}{l}15 \\
(13.6 \%)\end{array}$ & $\begin{array}{l}48 \\
(43.6 \%)\end{array}$ & 110 & \\
\hline 4 & $\begin{array}{l}32 \\
(38.1 \%)\end{array}$ & $\begin{array}{l}11 \\
(13.1 \%)\end{array}$ & $\begin{array}{l}12 \\
(14.3 \%)\end{array}$ & $\begin{array}{l}29 \\
(34.5 \%)\end{array}$ & 84 & \\
\hline 5 and above & $\begin{array}{l}14 \\
(58.3 \%)\end{array}$ & $2(8.3 \%)$ & $\begin{array}{l}5 \\
(20.8 \%)\end{array}$ & $\begin{array}{l}3 \\
(12.5 \%)\end{array}$ & 24 & \\
\hline Total & $\begin{array}{l}111 \\
(31.4 \%)\end{array}$ & $\begin{array}{l}72 \\
(20.4 \%)\end{array}$ & $\begin{array}{l}63 \\
(17.8 \%)\end{array}$ & $\begin{array}{l}107 \\
(30.3 \%)\end{array}$ & 353 & \\
\hline Number of earning members & & & & & & 0.001 \\
\hline
\end{tabular}




\begin{tabular}{|c|c|c|c|c|c|c|}
\hline Characteristics & OOPE* & $H I^{\star *}$ & Both & Others & Total & $\begin{array}{l}p \\
\text { value }\end{array}$ \\
\hline 1 & $\begin{array}{l}34 \\
(21.4 \%)\end{array}$ & $27(17 \%)$ & $\begin{array}{l}13 \\
(8.2 \%)\end{array}$ & $\begin{array}{l}85 \\
(53.5 \%)\end{array}$ & 159 & \\
\hline 2 & $\begin{array}{l}59 \\
(38.6 \%)\end{array}$ & $\begin{array}{l}34 \\
(22.2 \%)\end{array}$ & $\begin{array}{l}40 \\
(26.1 \%)\end{array}$ & $\begin{array}{l}20 \\
(13.1 \%)\end{array}$ & 153 & \\
\hline 3 and above & $\begin{array}{l}18 \\
(43.9 \%)\end{array}$ & $\begin{array}{l}11 \\
(26.8 \%)\end{array}$ & $\begin{array}{l}10 \\
(24.4 \%)\end{array}$ & $2(4.9 \%)$ & 41 & \\
\hline Total & $\begin{array}{l}111 \\
(31.4 \%)\end{array}$ & $\begin{array}{l}72 \\
(20.4 \%)\end{array}$ & $\begin{array}{l}63 \\
(17.8 \%)\end{array}$ & $\begin{array}{l}107 \\
(30.3 \%)\end{array}$ & 353 & \\
\hline Gross Monthly Income & & & & & & 0.001 \\
\hline less than Rs.20000 & $\begin{array}{l}21 \\
(30.4 \%)\end{array}$ & $\begin{array}{l}11 \\
(15.9 \%)\end{array}$ & $2(2.9 \%)$ & $\begin{array}{l}35 \\
(50.7 \%)\end{array}$ & 69 & \\
\hline Rs. 20000 to Rs. 30000 & $\begin{array}{l}22 \\
(25.3 \%)\end{array}$ & $\begin{array}{l}31 \\
(35.6 \%)\end{array}$ & $\begin{array}{l}10 \\
(11.5 \%)\end{array}$ & $\begin{array}{l}24 \\
(27.6 \%)\end{array}$ & 87 & \\
\hline Rs. 30000 to Rs. 50000 & $\begin{array}{l}23 \\
(23.5 \%)\end{array}$ & $\begin{array}{l}14 \\
(14.3 \%)\end{array}$ & $\begin{array}{l}24 \\
(24.5 \%)\end{array}$ & $\begin{array}{l}37 \\
(37.8 \%)\end{array}$ & 98 & \\
\hline More than Rs. 50000 & $\begin{array}{l}45 \\
(45.5 \%)\end{array}$ & $\begin{array}{l}16 \\
(16.2 \%)\end{array}$ & $\begin{array}{l}27 \\
(27.3 \%)\end{array}$ & $\begin{array}{l}11 \\
(11.1 \%)\end{array}$ & 99 & \\
\hline Total & $\begin{array}{l}111 \\
(31.4 \%)\end{array}$ & $\begin{array}{l}72 \\
(20.4 \%)\end{array}$ & $\begin{array}{l}63 \\
(17.8 \%)\end{array}$ & $\begin{array}{l}107 \\
(30.3 \%)\end{array}$ & 353 & \\
\hline $\begin{array}{l}\text { Monthly \% of income spent on } \\
\text { health }\end{array}$ & & & & & & 0.001 \\
\hline less than $5 \%$ & $\begin{array}{l}44 \\
(25.6 \%)\end{array}$ & $\begin{array}{l}26 \\
(15.1 \%)\end{array}$ & $\begin{array}{l}16 \\
(903 \%)\end{array}$ & $86(50 \%)$ & 172 & \\
\hline $5-10 \%$ & $\begin{array}{l}38 \\
(30.4 \%)\end{array}$ & $\begin{array}{l}41 \\
(32.8 \%)\end{array}$ & $\begin{array}{l}33 \\
(26.4 \%)\end{array}$ & $\begin{array}{l}13 \\
(10.4 \%)\end{array}$ & 125 & \\
\hline $10-20 \%$ & $\begin{array}{l}26 \\
(55.3 \%)\end{array}$ & $\begin{array}{l}5 \\
(10.6 \%)\end{array}$ & $\begin{array}{l}12 \\
(25.5 \%)\end{array}$ & $4(8.5 \%)$ & 47 & \\
\hline More than $20 \%$ & $\begin{array}{l}3 \\
(33.3 \%)\end{array}$ & $0(0 \%)$ & $\begin{array}{l}2 \\
(22.2 \%)\end{array}$ & $\begin{array}{l}4 \\
(44.4 \%)\end{array}$ & 9 & \\
\hline Total & $\begin{array}{l}111 \\
(31.4 \%)\end{array}$ & $\begin{array}{l}72 \\
(20.4 \%)\end{array}$ & $\begin{array}{l}63 \\
(17.8 \%)\end{array}$ & $\begin{array}{l}107 \\
(30.3 \%)\end{array}$ & 353 & \\
\hline Gross Expenditure happened on & & & & & & 0.001 \\
\hline$O P D$ basis treatment & $\begin{array}{l}36 \\
(31.6 \%)\end{array}$ & $\begin{array}{l}19 \\
(16.7 \%)\end{array}$ & $\begin{array}{l}11 \\
(906 \%)\end{array}$ & $\begin{array}{l}48 \\
(42.1 \%)\end{array}$ & 114 & \\
\hline
\end{tabular}

* Out of pocket Expenditure ** Health Insurance 


\begin{tabular}{|c|c|c|c|c|c|c|}
\hline Characteristics & OOPE* & $H \|^{\star *}$ & Both & Others & Total & $\begin{array}{l}\mathrm{p} \\
\text { value }\end{array}$ \\
\hline IPD/Hospitalization & $\begin{array}{l}22 \\
(23.9 \%)\end{array}$ & $\begin{array}{l}31 \\
(33.7 \%)\end{array}$ & $\begin{array}{l}30 \\
(32.6 \%)\end{array}$ & $9(9.8 \%)$ & 92 & \\
\hline Pharmacy/Medicine purchase & $\begin{array}{l}46 \\
(43.4 \%)\end{array}$ & $\begin{array}{l}15 \\
(14.2 \%)\end{array}$ & $17(16 \%)$ & $\begin{array}{l}28 \\
(26.4 \%)\end{array}$ & 106 & \\
\hline Laboratory Test/Imaging & $\begin{array}{l}7 \\
(17.1 \%)\end{array}$ & $\begin{array}{l}7 \\
(17.1 \%)\end{array}$ & $\begin{array}{l}5 \\
(12.2 \%)\end{array}$ & $\begin{array}{l}22 \\
(53.7 \%)\end{array}$ & 41 & \\
\hline Total & $\begin{array}{l}111 \\
(31.4 \%)\end{array}$ & $\begin{array}{l}72 \\
(20.4 \%)\end{array}$ & $\begin{array}{l}63 \\
(17.8 \%)\end{array}$ & $\begin{array}{l}107 \\
(30.3 \%)\end{array}$ & 353 & \\
\hline $\begin{array}{l}\text { Which of the Following Disease } \\
\text { incurred expenditure }\end{array}$ & & & & & & 0.001 \\
\hline Diabetes \& related condition & $\begin{array}{l}13 \\
(38.2 \%)\end{array}$ & $\begin{array}{l}7 \\
(20.6 \%)\end{array}$ & $\begin{array}{l}4 \\
(11.8 \%)\end{array}$ & $\begin{array}{l}10 \\
(29.4 \%)\end{array}$ & 34 & \\
\hline $\begin{array}{l}\text { Hypertension \& heart related } \\
\text { disease }\end{array}$ & $\begin{array}{l}25 \\
(28.4 \%)\end{array}$ & $\begin{array}{l}24 \\
(27.3 \%)\end{array}$ & $\begin{array}{l}28 \\
(31.8 \%)\end{array}$ & $\begin{array}{l}11 \\
(12.5 \%)\end{array}$ & 88 & \\
\hline Chronic Respiratory Disease & $\begin{array}{l}9 \\
(40.9 \%)\end{array}$ & $\begin{array}{l}4 \\
(18.2 \%)\end{array}$ & $\begin{array}{l}6 \\
(27.3 \%)\end{array}$ & $\begin{array}{l}3 \\
(13.6 \%)\end{array}$ & 22 & \\
\hline Cancer related conditions & $\begin{array}{l}5 \\
(100 \%)\end{array}$ & $0(0.0 \%)$ & $0(0.0 \%)$ & $0(0.0 \%)$ & 5 & \\
\hline Acute diseases & $\begin{array}{l}59 \\
(28.9 \%)\end{array}$ & $\begin{array}{l}37 \\
(18.13 \%)\end{array}$ & $\begin{array}{l}25 \\
(12.25 \%)\end{array}$ & $\begin{array}{l}83 \\
(40.68 \%)\end{array}$ & 204 & \\
\hline Total & $\begin{array}{l}111 \\
(31.4 \%)\end{array}$ & $\begin{array}{l}72 \\
(20.4 \%)\end{array}$ & $\begin{array}{l}63 \\
(17.8 \%)\end{array}$ & $\begin{array}{l}107 \\
(30.3 \%)\end{array}$ & 353 & \\
\hline
\end{tabular}

\section{Determinants and mode of availing health services}

Table 2 shows the significant relationship between independent variables and different modes of availing the various healthcare services. It was found that factors like area of residence, gender, age, marital status, education and number of earning members in the family, gross monthly income, percentage of income spent on healthcare had direct significant relationship with the various modes of availing health care services. Among the study group, $62.8 \%$ households from rural area and $71.4 \%$ from urban slum area prefer OOPE; $33.7 \%$ male and $29 \%$ female prefer OOPE; whereas $43.2 \%$ female prefer other options for availing health services.51.8\% of households within 18-25 years age group and $43.8 \%$ of households above 60 years of age opt for OOPE. $41.7 \%$ unmarried households opt for OOPE, 35.2\% married households opt for other modes of availing healthcare services. Educated people use both OOPE and health insurance facilities with more inclination towards OOPE; but among the households with school level education only $7.9 \%$ use health insurance as mode of availing health services.53.5\% of households with one earning member opt for other modes of availing health services whereas households with more 
earning members opt for OOPE as mode of availing health services.45.5\% of households from upper income group (above 50000 INR per month) opt for OOPE; 50.7\% from lower income group (less than 20000 INR per month) use other modes.50\% households who spend less than $5 \%$ monthly income on health opt for other modes of availing healthcare services and with increase in percentage of monthly expenditure on health, percentage of OOPE also increases. Whereas factors like occupation and number of dependent members in family just have a significant relationship with the various modes of availing healthcare services.42.1\% government employees, $33.8 \%$ private employees, $26.1 \%$ employees with other occupation opt for OOPE whereas $49.5 \%$ of households with other occupation opt for other options as mode for availing health services. OOPE is highest in all categories except those households where dependent members are 3 .

\section{Distribution and mode of availing health services:}

It was also found that Type of disease had significant relationship with mode of availing health services. Among non-communicable disease (NCD) cases; $100 \%$ cancer cases, $40.9 \%$ chronic respiratory disease cases, $38.2 \%$ diabetes and related condition cases, $28.4 \%$ hypertension and heart related disease cases and $28.9 \%$ of acute disease cases opt for OOPE mode for availing health care services (Graph-1). Also gross expenditure i.e. distribution of expenditure had significant relationship with mode of availing health services. $43.4 \%$ expenditure was on medicine purchase, $31.6 \%$ was on OPD basis treatment and $23.9 \%$ was on IPD based treatment. Thus highest expenditure was found to be on medicine purchase. Figure no. 1. depicts diseases wise distribution among all cases of OOPE.

\section{Graph-1: Distribution of Mode of expenditure (in \%)}

\section{Discussion}

In India, the proportion of households with more than 10\% OOPE for healthcare has increased more than two times during 2004-2014(16). OOP payment is a major portion of total health expenditure in India as public investment in healthcare is the lowest. The goal of National Health Policy 2017 was to achieve significant reduction in OOP payments, catastrophic health expenditure and impoverishment due to health expenditure (17). This study was conducted to find out impact of socioeconomic, demographic and educational factors on OOPE and distribution of OOPE among various components of healthcare services and diseases among the households of Pune districts of Maharashtra State of India. Pune district was selected as it resembles mixed strata of urban, urban slum, and rural population of different demographic as well as socioeconomic characteristics.

Findings of the study were as follows OOPE was higher in urban slum and rural households as well as households headed by males. Also OOPE was higher with 18-25 years of age group and households above 60 years of age. Unmarried, highly educated individuals, households with more earning members, less dependent members, more gross monthly income also opt for higher OOPE. The higher incidence of OOPE in the above groups could be because of lack of access to public funded health facility for appropriate treatment, less awareness about available health financing options, negative perception 
towards quality of public healthcare services and comparatively good quality of services provided at private hospitals $(1,2,18-22)$. In urban slum and rural areas people ignore small health issues to avoid expenditure $(1,2,22)$ and they seek help when problem becomes severe; also they have limited options available and known to them. In case of emergency, access to services in public hospitals is difficult due to long waiting time and at the same point of time poor quality of care, lack of infrastructure forcing them to opt for private organization that increases OOPE(23-25). On the other hand OOPE is higher among households managed by males and between 18-25 years age households, which may be due to more economic resources with better physical access which further increases utilization(16). Whereas among households above 60 years of age, OOPE increases as healthcare needs, dependency on medication increases with age, also working capacity of this age group decreases which adds to the economic burden, they also lose their employer insurance cover post retirement and personal insurance premiums become expensive with increasing age.(16, 26-29)

Availability of resources and more preferences to private healthcare facilities $(16,20)$ could be the reason for increased OOPE among the educated households, households with more earning members, households with more monthly income, households with less dependent members. Urbanization, industrialization and increased life expectancy have increased the prevalence of NCDs in India in the coming years.(30) According to National Health Accounts estimates (2014-15), households in India face high financial burden with $62.5 \%$ OOP payment of total health expenditure, which is due to high cost of treatment of NCDs.(31) Kastor A et al had suggested that the disease pattern has a direct link with the volume and type of health services needed which subsequently has an impact on the health expenditure. (29) As per this study chronic diseases top the list when it comes to OOPE followed by acute diseases. Collective study conducted by Public health foundation of India and Institute Of Health Metrics And Evaluation in various states had shown that the treatment cost for NCDs is usually high in India(32)which may be due to much of the care for NCDs is provided in the private sector. $(20,30)$ As per the gross expenditure it was found that highest expenditure was on medicine purchase. According to the report of WHO, around $68 \%$ of Indian population has limited or no access to essential medicines. (33)Also availability of free medicine in public health facilities has declined in India from 31.2-8.9\% for inpatient care and from $17.8-5.9 \%$ for outpatient care (34) and medicine purchase alone constitutes $70 \%$ of overall OOP payments.(35) The results of our study are also consistent with these findings.

The findings of this study suggest that various factors affect OOPE so public health expenditure should be increased to improving the competence of healthcare facility. Government should facilitate establishment of charitable trust based health facilities across the rural \& urban slum area, increasing corporate social responsibility (CSR) funded mobile clinic or government supported or sponsored mohalla clinic and maintain supply of essential and generic medicine may reduce OOPE.

Our study captured the determinants and distribution of OOPE among households of Pune district. However, the study has some limitations. Sample size is small; details of expenditure are recorded in terms of percentage. Respondents are not children and details of expenditure were recorded against whole household not against each member of household in this study so in-depth evaluation as per 
family member was not possible in this study. Additionally, it is of course possible for some people not to have incurred OOP expenditures not because they were not in need of health services, but because they were not able to afford them; assessing this phenomenon was not possible with the current dataset and remains a task for future research.

\section{Conclusion}

Considering the limitations, this study suggests that the demographic, socioeconomic and educational factors should be considered while formulating the healthcare policies. Government should increase public healthcare expenditure. There is need to develop policy options for building stronger financial protection mechanisms in India. Implementation of existing social insurance scheme and increasing the penetration of the same may help to reduce OOPE. Government should improvise existing healthcare facility to cover NCD burden and simultaneously maintain supply of essential and generic medicine at public healthcare facilities to reduce OOPE.

\section{Abbreviations}

OOPE: out of pocket expenditure

GDP: gross domestic product

OPD: outpatient department

IPD: inpatient department

INR: Indian rupee

NCDs: non-communicable diseases

CSR: corporate social responsibility

\section{Declarations}

\section{Authors' contributions}

Idea for article: Dr. Prakash Kalke

Literature search: Dr. Prakash Kalke, Dr. Darshana Mundhe, Manuscript Writing: Dr. Darshana Mundhe, Dr. Prakash Kalke, Dr. DharmendraKumar Dubey Consent for publication - NA. 
Consent to participate - Informed consent was obtained from all subjects or, if subjects are under 18 , from a parent and/or legal guardian.

Competing Interests Declaration: We have read and understood publishing policy on declaration of interests and declare that we have no competing interests.

Funding: The authors have not declared a specific grant for this research from any funding agency in the public, commercial or not-for-profit sectors.

Acknowledgements: This study is a part of subjective assignment of Students; appreciate all students who have participated during data collection.

Ethics approval - All methods were carried out in accordance with SIU Pune guidelines and regulations" All experimental protocols and methods were approved by an institutional AIC of SIHS.

Availability of data and materials - The datasets generated and/or analysed during the current study are not publicly available due to SIU policy but are available from the corresponding author on reasonable request.

\section{References}

1. Sekher TV, Kumar K. Catastrophic Health Expenditure and Poor in India: New Evidence from a Nationwide Survey. IUSSP Conf. 2012;

2. Ekman B. Catastrophic health payments and health insurance: Some counterintuitive evidence from one low-income country. Health Policy (New York). 2007;

3. Van Doorslaer E, O'Donnell O, Rannan-Eliya RP, Somanathan A, Adhikari SR, Garg CC, et al. Catastrophic payments for health care in Asia. Health Econ. 2007;

4. WHO. World Health Organization Global Health Expenditure database [Internet]. 2016. Available from: http://apps.who.int/nha/database

5. Xu K, Evans DB, Carrin G, Aguilar-Rivera AM, Musgrove P, Evans T. Protecting households from catastrophic health spending. Health Aff. 2007;

6. Ministry of Statistics and Programme Implementation G, India O. India - social consumption. Health, NSS 71st round: Jan-June 2014 [Internet]. New Delhi; 2016. Available from: http://mail.mospi.gov.in/index.php/\%0Acatalog/161

7. (NewIndiaExpress) SSD. No Title. New India Express [Internet]. 2019; Available from: https://www.newindianexpress.com/nation/2019/nov/01/indias-public-expenditure-on-health-lessthan-lower-income-countries-government-data-2055553.html

8. World Health, Organization G. Global health expenditure database [Internet]. Online Data Base. 2014. Available from: http://apps.who.int/nha/\%0Adatabase 
9. Garg CC, Karan AK. Reducing out-of-pocket expenditures to reduce poverty: A disaggregated analysis at rural-urban and state level in India. Health Policy Plan. 2009;

10. Da Silva MT, Barros AJD, Bertoldi AD, De Andrade Jacinto P, Matijasevich A, Santos IS, et al. Determinants of out-of-pocket health expenditure on children: An analysis of the 2004 Pelotas Birth Cohort. Int J Equity Health. 2015;

11. Phillips DP, Christenfeld N, Glynn LM. Increase in US medication-error deaths between 1983 and 1993. Lancet. 1998;

12. Kien VD, Van Minh H, Giang KB, Dao A, Tuan LT, Ng N. Socioeconomic inequalities in catastrophic health expenditure and impoverishment associated with non-communicable diseases in urban Hanoi, Vietnam. Int J Equity Health. 2016;

13. Saito E, Gilmour S, Rahman MM, Gautam GS, Shrestha PK, Shibuya K. Catastrophic household expenditure on health in Nepal: a cross-sectional survey. Bull World Health Organ. 2014;

14. Lee WY, Shaw I. The Impact of Out-of-Pocket Payments on Health Care Inequity: The Case of National Health Insurance in South Korea. Int J Environ Res Public Health. 2014;

15. Wagstaff A, van Doorslaer E. Chapter 34 Equity in health care finance and delivery. Handbook of Health Economics. 2000.

16. Pandey A, Ploubidis GB, Clarke L, Dandona L. Trends in catastrophic health expenditure in india: 1993 to 2014. Bull World Health Organ. 2018;96(1):18-28.

17. Ministry of Health and Family Welfare; Government of India. National Health Policy 2017. 2017.

18. Pandey A, Ploubidis GB, Clarke L, Dandona L. Trends in catastrophic health expenditure in india: 1993 to 2014. Bull World Health Organ. 2018;

19. Pandey A, Anil Kumar G, Dandona R, Dandona L. Variations in catastrophic health expenditure across the states of India: 2004 to 2014. PLoS One. 2018;13(10):1-15.

20. Barik D, Arokiasamy P. Rising health expenditure due to non-communicable diseases in India: An outlook. Front Public Heal. 2016;4(NOV).

21. Karan A, Selvaraj S, Mahal A. Moving to universal coverage? Trends in the burden of out-of-pocket payments for health care across social groups in India, 1999-2000 to 2011-12. PLoS One. 2014;

22. Pandey A, Anil Kumar G, Dandona R, Dandona L. Variations in catastrophic health expenditure across the states of India: 2004 to 2014. PLoS One. 2018;

23. Dror DM, van Putten-Rademaker O, Koren R. Cost of illness: Evidence from a study in five resourcepoor locations in India. Indian J Med Res. 2008;127(4).

24. Berman PA. Rethinking health care systems: private health care provision in India. World Dev. 1998;26(8).

25. Onwujekwe OE, Uzochukwu BSC, Obikeze EN, Okoronkwo I, Ochonma OG, Onoka CA, et al. Investigating determinants of out-of-pocket spending and strategies for coping with payments for healthcare in southeast Nigeria. BMC Health Serv Res. 2010; 
26. Sarker AR, Mahumud RA, Sultana M, Ahmed S, Ahmed W, Khan JAM. The impact of age and sex on healthcare expenditure of households in Bangladesh. Springerplus. 2014;

27. Mohanty SK, Chauhan RK, Mazumdar S, Srivastava A. Out-of-pocket Expenditure on Health Care Among Elderly and Non-elderly Households in India. Soc Indic Res. 2014;115(3).

28. Brinda EM, Rajkumar AP, Enemark U, Prince M, Jacob KS. Nature and determinants of out-of-pocket health expenditure among older people in a rural Indian community. Int Psychogeriatrics. 2012;24(10).

29. Kastor A, Mohanty SK. Disease-specific out-of-pocket and catastrophic health expenditure on hospitalization in India: Do Indian households face distress health financing? PLoS One. 2018;13(5).

30. Srinath Reddy K, Shah B, Varghese C, Ramadoss A. Responding to the threat of chronic diseases in India. Vol. 366, Lancet. 2005.

31. Centre NHSR. National Health Accounts Estimates for India (2013-14). New Delhi:Ministry of Health and Family Welfare, Government of India. 2016.

32. J.P. T, B. P, H.D. S, A.M. K, A.D. H. Cost of hospitalization for cardiovascular diseases in India: Are we pro-poor? Glob Heart. 2016;11(2).

33. WHO. The Word Medicine Situation 2004. Geneva: World Health Organisation. 2004.

34. K. R. High Level Expert Group (HLEG) report on Universal Health Coverage (UHC) for India. New Delhi: Public Health Foundation of India. 2011.

35. Shahrawat R, Rao KD. Insured yet vulnerable: Out-of-pocket payments and India's poor. Health Policy Plan. 2012;27(3).

\section{Figures}
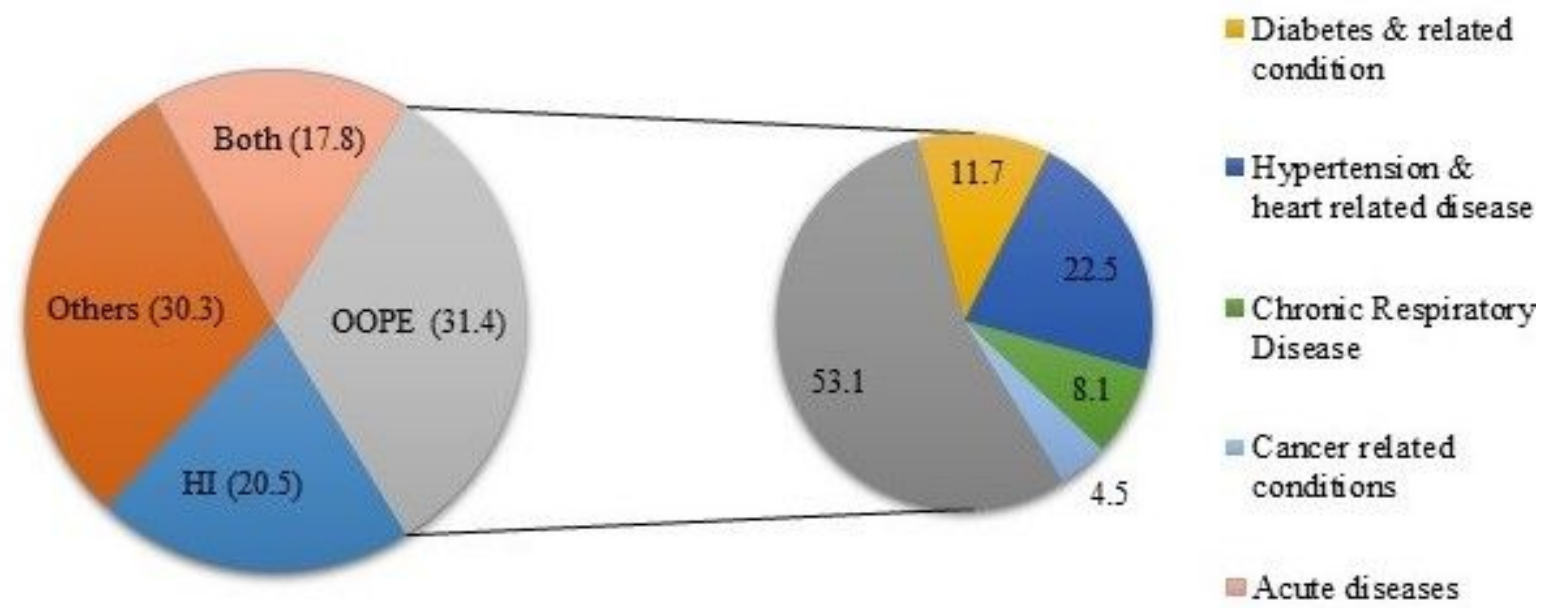

Figure 1 
Distribution of Mode of expenditure (in \%) 